\title{
Studies on the extension of shelf-life of fresh fruits and vegetables
}

VII. Effect of packaging with polyethylene bag on the pigment content of tomato fruits

\author{
Masutaro Окиво, Katsu Ishi and Keiji UмedA* \\ Chiba Agricultural Experiment Station, Daizenno-machi, Chiba
}

\section{Summary}

In order to elucidate the retardation of color development of tomato fruits packaged with polyethylene bag, changes of carotenoids in fresh fruits, especially colorless intermediates, were investigated.

1. During the ripening of tomatoes after harvest, chlorophyll content in tomato fruit decreased, while lycopene content increased sharply.

2. When coloring of tomatoes was controlled by packaging with polyethylene bag, both of the decreasing of chlorophyll and the formation of lycopene were suppressed, but carotene contents slightly increased as well as in unpackaged fruits.
3. In the packaged fruits containing little lycopene, abnormal accumulation of colorless carotenoids, phytoene and phytofluene, were not observed, although much content of them were found in unpackaged fruits which contained much content of lycopene.

4. From the above results, it is assumed that the suppression of lycopene formation in tomato fruits packaged with polyethylene bag is not controlled by inhibition of dehydrogenation of phytoene and phytofluene, colorless carotenoids, but by the lack of intermediates which might have formed in the pathway from terpenyl pyrophosphate to phytoene.

\section{Introduction}

The biosynthetic pathway regarding carotenoids formation in microorganisms, higher plants and animals have been studied by many workers in recent years $\mathbf{s}^{1,3,4,5,6,7,8,16,20,24)}$. In tomato fruits, it is generally recognized that phytoene, a sort of colorless polyene, is the first 40-C compound formed as a precursor of carotenoids ${ }^{1,2,16)}$, although there are a few objection ${ }^{17,19,20)}$.

On the other hand, Purcell et al. ${ }^{17)}$ have shown that the unknown compounds which are considered intermediates of carotenoids are abnormally accumulated in tomato fruits stored at low temperature. RiLling ${ }^{18)}$ has also reported that phytoene and phytofluene are abnormally accumulated in microorganisms when biosynthesis of carotenoids is inhibited by diphenylamine. It is expected that such a phenomenon would occur in tomato fruits packaged with polyethylene bag as well as in microorganisms. In order to clarify this point, phytoene and phytofluene as colorless intermediates in lycopene biosynthesis, lycopene and chlorophyll were determined in both tomato fruits packaged with polyethylene bag and unpackaged.

\section{Materials and Methods}

\section{Materials}

Tomatoes (Fukuju No.2) were cultivated in plastic house, in Kazusa-ichinomiya-machi, Chiba and were picked at the turning stage (ripeness score 2 or $3^{13)}$ ) from 9 to 11 a.m.

The weight of every fruit was in the range of 130-160 g. Packaging method with poly-

Received for publication July 20, 1970

* Food Research Institute, Ministry of Agriculture and Forestry, Koto-ku, Tokyo 


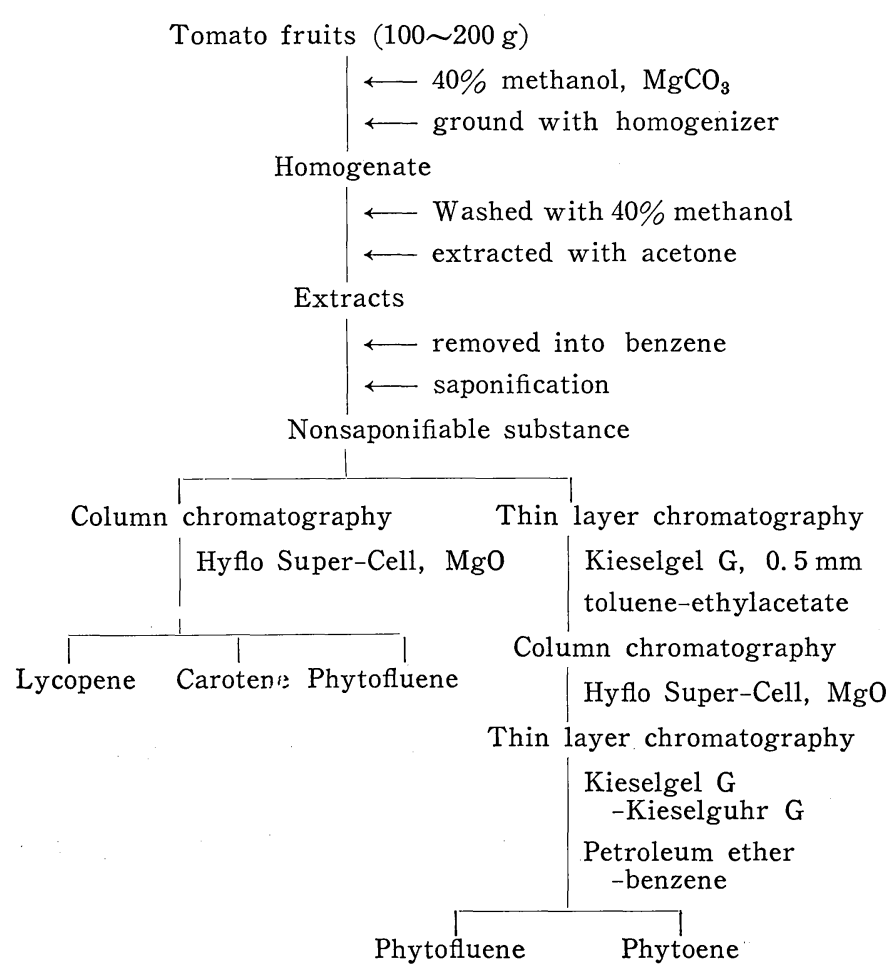

Fig. 1. Extraction and separation of tomato carotenoids.

ethylene bag was reported in the previous paper ${ }^{13)}$.

\section{Methods}

Preparation and analytical methods are shown in Fig. 1. Tomato fruits were sliced and mixed after seeds were removed and $100-200 \mathrm{~g}$ of the slices were ground and washed with $40 \%$ methanol ${ }^{23)}$. The pigments and colorless intermediates were extracted with acetone. A part of acetone fraction was transferred to diethylether with the aid of water, and chlorophyll content was determined according to SMITHBenitez $^{21)}$. For analysis of carotenoids, another part of acetone fraction was similarly transferred to benzene. After saponification with $7 \%$ (weight for volume) ethanolic $\mathrm{KOH}^{10)}$ at room temperature $\left(15-18^{\circ} \mathrm{C}\right)$ the nonsaponifiable fraction was washed free from alkali with $50-60 \%$ methanol and salted out with $5 \% \mathrm{NaCl}$ solution and washed again with water.

\section{Separation and determination of phytofluene and colored carotenoids}

The above mentioned nonsaponifiable fraction was chromatographed on a $2.5 \times 20 \mathrm{~cm}$ column of Hyflo Super-Cell : MgO (1:1 weight for weight) according to Purcell et al. ${ }^{17)}$ Hyflo SuperCell and $\mathrm{MgO}$ were sifted through a 100 and a 50 mesh-sieve respectively before the use. After the carotene fraction was placed on the column, it was developed with hexane, and the condition of the separation on column was observed under ultraviolet light. When the phytofluene band progressed about halfway down on the column, $2 \%$ acetone in hexane was added rapidly to develop phytofluene to the bottom of the column. The other fractions were sequentially eluted by increasing concentrations of acetone up to $10 \%$, followed by addition of increasing concentrations of methanol up to $2 \%$ for elution of lycopene. Phytofluene fraction could be separated as fluorescent band under ultraviolet light. In this fraction the absorption characterizing sterol was also observed under ultraviolet light (Fig. 2). But there is no possibility of the unfavorable effect by this absorption on determining the value of phytofluene, because this was observed at $275-285 \mathrm{~m} \mu$, and phytofluene was determined by the optical absorbency at $348 \mathrm{~m} \mu$ in pet-ether. Pet-ether was run through a column of silica-gel (Wakogel) and further purified with distillation prior to using.

$\alpha-, \beta-, \gamma-$ and $\delta$-Carotene were found respectively by absorption curves in visible spectrum, but they were concentrated without separating each other, and determined by the absorbency at $450 \mathrm{~m} \mu$ in pet-ether and expressed as $\beta$-carotene. Lycopene, phytofluene and phytoene were 


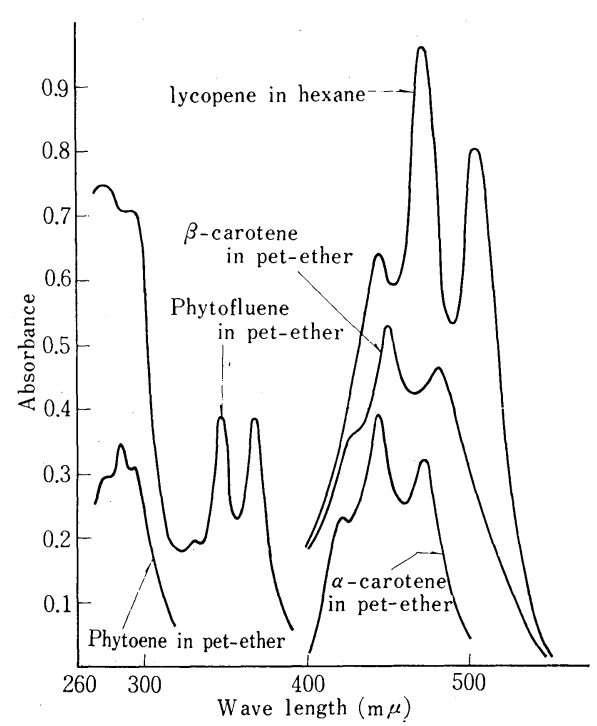

Fig. 2. Absorption spectra of tomato carotenoids separated with column and thin layer chromatography.

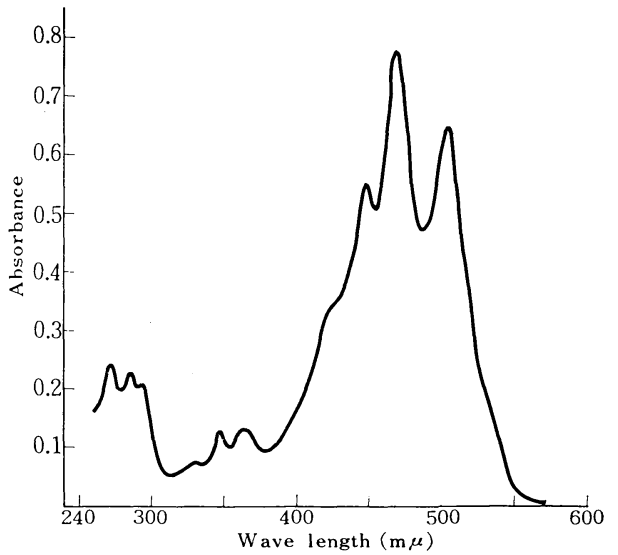

Fig. 3. Absorption spectra of front fraction on T. L.C. (Kieselgel G $0.5 \mathrm{~mm}$ ) developed with toluen-ethylacetate.

determined by absorbency at $472 \mathrm{~m} \mu, 348 \mathrm{~m} \mu$ and $285 \mathrm{~m} \mu$ respectively.

Their contents were calculated by the

following equation ;

$$
X(\mathrm{mg})=\frac{E_{\nu} \times F \times 1000}{E_{1 \mathrm{~cm}}^{1 \%} \times 100}
$$

Where $E_{y}=$ value of OD given at its wavelength of maximal absorption when $X \mathrm{mg}$ of sample was dissolved in $Y \mathrm{~m} l$ solvent.

\section{$F=$ magnification of dilution}

$E_{1 \mathrm{~m}}^{1 \%}=$ the specific coefficient for each carotenoid indicated below.

$$
\begin{aligned}
& \text { lycopene (in hexane) } \cdots \cdots \cdot 3,450 \\
& \beta \text {-carotene (in pet-ether) } \cdots \cdots \cdot 2,505 \\
& \text { phytofluene ( } \prime \prime \quad) \cdots \cdot \cdot 1,350 \\
& \text { phytoene ( } \quad \text { " }) \cdots \cdot \cdot 1,250
\end{aligned}
$$

\section{Separation and purification of phytoene}

As shown in Fig. 1, for separation and purification of phytoene, other part of the nonsaponifiable fraction, after concentration, was chromatographed on a $0.5 \mathrm{~mm}$ thin layer of Kieselgel $\mathrm{G}^{9,11)}$ which was activated at $120^{\circ} \mathrm{C}$ for $45 \mathrm{~min}$ prior to using. As developing reagents, toluene and ethyl acetate $(9: 1)$ were used. Spotting and development were carried out in $\mathrm{N}_{2}$ gas. The bands of most carotenoids gathered at the solvent front. The absorption spectra of these carotenoids in pet-ether are shown in Fig. 3. As a small amount of sterol still exists, further purification was carried out. Namely the carotenoids treated as described above were chromatographed on a column of Hyflo Super-Cell and $\mathrm{MgO}$, and phytoene and phytofluene (fluorescent and pre-fraction) were separated from colored carotenoids, followed by thin layer chromatography. Kieselgel $\mathrm{G}$ and Kieselguhr $\mathrm{G}$ (1:1 weight for weight, $0.2 \mathrm{~mm}$ in thickness) were used after being activated at $120^{\circ} \mathrm{C}$ for one hour previously. Development was carried out with pet-ether-benzene which was prepared by distillating a mixture of pet-ether and benzene at $60-80^{\circ} \mathrm{C}$. The phytoene fraction was considered to be almost free from sterol and 
the absorption curves for phytoene, phytofluene, $\beta$-carotene and lycopene which were obtained by the above methods are shown in Fig. 2 .

\section{Results and Discussion}

\section{Changes of chlorophyll content}

As shown in Table 1, when tomato fruits were not packaged, ripeness score rose and chlorophyll content in fruits decreased rapidly with ripening, and while when fruits were packaged with polyethylene bag, the after-ripening of the fruits was controlled and chlorophyll did not decrease so rapidly. It was recognized that the packaging with polyethylene bag is effective to keep the color of fruit green ${ }^{12)}$.

\section{Changes of the colored carotenoids content}

Carotene. The visible absorption spectrum of individual carotene separated by column chromatography showed the presence of $\alpha^{-}, \beta-, \gamma-$, and $\delta$-carotene. These carotenes were combined and expressed as $\beta$-carotene which may be a major component of carotenes in tomato fruits. As shown in Table 2, coloring of unpackaged fruits developed rapidly but carotenes increased slowly. The difference of carotene content between packaged and unpackaged fruits was small. TAKAHASHI ${ }^{22}$ reported that carotenes increased with ripening of tomatoes and the authors also observed $^{15)}$ the same phenomenon about controlled culture using Goko variety but the content

Table 1. Changes of ripeness score and chlorophyll content of tomato fruits during storage at $24^{\circ} \mathrm{C}$.

\begin{tabular}{c|lll}
\hline \hline & 0 day* & 2 days & 5 days \\
\hline Nonpackaging $\left\{\begin{array}{l|ll}\text { Chlorophyll }(\mathrm{mg} / 100 \mathrm{~g}) \\
\text { Ripeness score }\end{array}\right.$ & 0.90 & 0.37 & 0.05 \\
Packaging with & 2 & 5 & 9 \\
polyethylene bag $\left\{\begin{array}{l}\text { Chlorophyll }(\mathrm{mg} / 100 \mathrm{~g}) \\
\text { Ripeness score }\end{array}\right.$ & 0.90 & 0.71 & 0.83 \\
\end{tabular}

* Days after harvest

Table 2. Effect of packaging with polyethylene bag on colored carotenoids content of tomato fruits during storage at $24^{\circ} \mathrm{C}$.

\begin{tabular}{l|ccc|ccc}
\hline \multirow{2}{*}{ Treatments } & \multicolumn{2}{|c|}{ Lycopene $(\mathrm{mg} / 100 \mathrm{~g})$} & \multicolumn{2}{|c}{ Carotene $(\mathrm{mg} / 100 \mathrm{~g})$} \\
\cline { 2 - 6 } & 0 day* & 2 days & 5 days & 0 day* & 2 days & 5 days \\
\hline $\begin{array}{l}\text { Nonpackaging } \\
\begin{array}{c}\text { Packaging with } \\
\text { polyethylene bag }\end{array}\end{array}$ & 0.17 & 1.46 & 4.50 & 0.35 & 0.40 & 0.39 \\
\hline
\end{tabular}

* Days after harvest

Table 3. Effect of packaging with polyethylene bag on colorless carotenoids content of tomato fruits during storage at $24^{\circ} \mathrm{C}$.

\begin{tabular}{|c|c|c|c|c|c|c|}
\hline \multirow{2}{*}{ Treatments } & \multicolumn{3}{|c|}{ Phytoene (mg/100 g) } & \multicolumn{3}{|c|}{ Phytofluene $(\mathrm{mg} / 100 \mathrm{~g})$} \\
\hline & 0 day* & 2 days & 5 days & 0 day* & 2 days & 5 days \\
\hline Nonpackaging & 0.21 & 0.60 & 0.85 & 0.04 & 0.14 & 0.32 \\
\hline $\begin{array}{l}\text { Packaging with } \\
\text { polyethylene bag }\end{array}$ & 0.21 & 0.24 & 0.30 & 0.04 & 0.03 & 0.02 \\
\hline
\end{tabular}

* Days after harvest of these substances is not so large as lycopene. Carotene is not the principal component of carotenoids in tomato fruit and does not affect the color development of the fruit. Tomato fruits become colored when content of chlorophyll decreases as described before and lycopene increase as it will be stated later.

Lycopene. As shown in Table 2 , lycopene in unpackaged fruits was rapidly formed with normal progress of ripening. On the other hand, in packaged fruits with polyethylene bag lycopene was formed very slowly. It was confirmed that coloring of tomato fruits was almost based upon increase of lycopene which it was previously sug gested $^{14)}$ from changes of main-wave length determined by NIHON DENSHOKU P II 
type using tomato fruit homogenates.

\section{Changes of content of the colorless carotenoids}

Changes of content of phytoene and phytofluene which are considered to be the first 40-C compound formed as intermediates in carotenoid biosynthesis are shown in Table 3. Content of phytoene in fruit was larger than that of phytofluene, but both content of these colorless carotenoids changed similarly as the ripening progress. In unpackaged fruits, both colorless carotenoids increased almost in proportion to lycopene. Considering the pathway of carotenoid biosynthesis, when lycopene increases rapidly, phytoene and phyeofluene, precursors of lycopene, are expected to be synthesized rapidly before lycopene appears. Neverthless not only much of these colorless carotenoids but much lycopene are determined at the same time, so it is probable that they are formed more than their conversion to lycopene. As colorless carotenoids appear keeping pace with lycopene, some investigators presume that they may be biosynthesized through different pathways ${ }^{19)}$.

In introduction of this report it was presumed that coloring of tomato fruit is controlled by packaging them with polyethylene bag and consequently colorless intermediates might abnormally accumulate by inhibition of their dehydrogenation as well as inhibition by diphenylamine in microorganism ${ }^{18)}$. But as the result of determination they were not accumulated so largely in packaged tomato fruits. Therefore the assumption stated in introduction is not right, but it would be right to say that the decline of lycopene formation is due to lack of phytoene and phytofluene which should be supplied during the ripening of fruit.

Purcell et al. ${ }^{17)}$ investigated on the mechanism of control of coloring of tomato fruits stored at low temperature and found that there was extremely large quantity of fraction eluted ahead of phytoene on the same column as that used by authors in tomato fruits stored at low temperature. They suggested that this was another intermediary substance of lycopene. However it is found that from their data, phytoene and phytofluene do not abnormally accumulate in fruits stored at low temperature, but in fruits stored at $25^{\circ} \mathrm{C}$ large quantity of phytoene and phytofluene do as well as lycopene is produced.

It is clear that slow progress of coloring of packaged tomato fruits is due to poor biosynthesis of lycopene. But it is not correct to explain the mechanism only from contents of phytoene or phytofluene in fruits, because when tomato fruits contains little lycopene, it does not contain much phytoene and phytofluene either. From these facts described above, the following conclusion is suggested. Lycopene formation in tomato fruits which were packaged with polyethylene bag would be prevented by an obstacle on the biosynthetic pathway from low molecular substances to phytoene (i.e., acetyl $\mathrm{CoA} \rightarrow$ mevalonic acid $\rightarrow$ isopentenyl pyrophosphate $\rightarrow$ farnesyl pyrophosphate $\rightarrow$ geranyl geranyl pyrophosphate $\rightarrow$ phytoene').

When tomato fruits are packaged air-tightly, this pathway becomes out of order and 40-C substances, phytoene and phytofluene, are not sufficiently made for formation of much lycopene. After all, one of the reasons why biosynthesis of lycopene becomes inactive in tomato fruit packaged with polyethylene bag is considered to be the lack of supply of phytoene and phytofluene.

\section{Acknowledgment}

The authors are grateful to Dr.K.Shibazaki, University of Tohoku, for his valuable guidances 
throughout the course of this work. The authors are also thankful to Dr. T. MAEZAwA, for helpful discussion and encouragement.

\section{References}

1. ANDERSON, D.G. and J.W.PoRTER. 1962. Arch. Biochem. Biophys. 97 : 509-519.

2. BEELER,D.A. and J. W. PORTER. 1962. Biochem. Biophys. Research. Commun. $8: 367-371$.

3. BRAithwaite, G. D. and J. W. GoodWin. 1960. Biochem. J. $76: 5-10$.

4. 1960 . Biochem. J. $76: 194$ $-197$.

5. DAVIS, B. H., D. Jones and T. W. GOODWIN. 1963. Biochem. J. $87: 326-329$.

6. GOODWIN, T. W. and M. JAMIKORN. 1952. Nature $170: 104-105$.

7. and H. G. OSMAN. 1954. Biochem. J. $56: 222-230$.

8. 1965. Chemistry and biochemistry of plant pigments. Academic press. London New york.

9. Hasegawa, K. 1968. Abst. Ann. Meeting, Agr. Chem. Soc. Japan.

10. KimURA, S. and T.Shibata. 1953. Report of the food research institute. No. $8: 219-221$.

11. LOWRY, L. K. and C. O. Chichester. 1967. Phytochem. $6: 367-370$.

12. MURATA, T., K. TATEISHI and K. OGATA. 1968. Jour. Jap. Soc. Hort. Sci. $37: 391-396$.

13. OKubo,M. and T.Maezawa. 1965. Bul. Chiba.
Agr. Exp. Sta. 6: 181-190.

14. 1967. Jour. Jap. Soc. Hort. Sci. $36: 462-466$

$15 . \quad$ and K. UMEDA. 1969. Abst. Spring Meeting, Jap. Soc. Hort. Sci. pp. 288-289.

16. Porter, J. W. and R. E. Lincoln. 1950. Arch. Biochem. Biophys. 27 : 390-403.

17. PurCell, A.E., G.A.JHOMPSON and J. BONNER. 1959. J. Biol. Chem. $234: 1081-1084$.

18. Rilling, H. C. 1965. Arch. Biochem. Biophys. $110: 39-46$.

19. Purcell, A. E. 1964. Arch. Biochem. Biophys. $105: 606-611$.

20. Shneour, E. A. and I. ZABin. 1957. J. Biol. Chem. $226: 861-866$.

21. Smith, J. H. C. and A. Benitez 1955. Modern methods of plant analysis. IV. 142, SpringerVerlag ; Berlin.

22. TAKAHASHI, K., K. TSUNODA, Y. TETSUZAKI and T.SugiYama. 1964. Journal of food science and technology (Japan) $11: 285-290$.

23. UMEDA, K. 1964. Abst. Ann. Meeting, Agr. Chem. Soc. Japan.

24. Yamamoto, H., H. YoKoyama, K. Simpson, T.O.M. NAKAYAMA and C.O. Chichester. 1961. Nature $191:$ 1299-1300.

\section{青果物の鮮度保持に関する研究（第7 報）}

トマトの色素含量に拉よぼすポリエチレン包装の影響

\section{大久保増太郎 - 石 井勝 - 梅田圭 司}

(千葉県農業試験場)

\begin{tabular}{|c|c|}
\hline 摘 & 要 \\
\hline 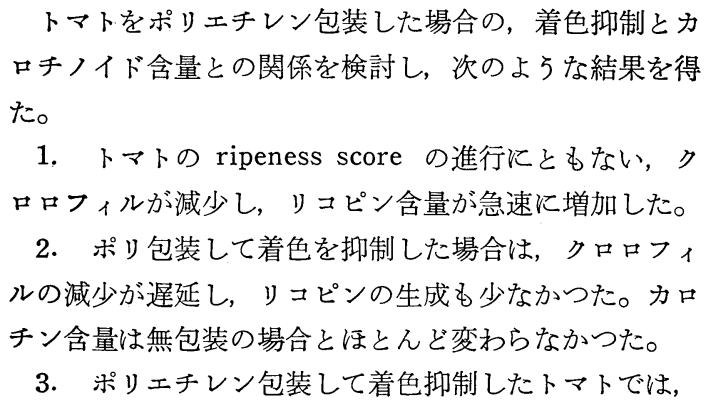 & $\begin{array}{l}\text { リコピン生合成の中間体と考号られる phytoene, phy- } \\
\text { tofluene などの無色のカロチノイドの生成は, リコピ } \\
\text { ン含量の多いもの泣多く, 逆にポリ包装してリコピン } \\
\text { の生成が少なかつたものは, それらの生成も少なかつ } \\
\text { た。 } \\
\text { 4. 以上のことから, ポリ包装によるリコピンの生成 } \\
\text { 阻害は, phytoene, phytofluene 以降の脱水素系の阻害 } \\
\text { ではなく, それ以前の phytoene の生合成経路の阻害と } \\
\text { 考えられた。 }\end{array}$ \\
\hline
\end{tabular}
phytoene の異常蓄積は認められなかつた。すなわち， 